\title{
Removal of Methylene Blue from Aqueous Solutions with Fly Ash Based Geopolymer Foam
}

\author{
Evren Arıöz ${ }^{1 *}$, Gözde Bahar Büke ${ }^{2}$

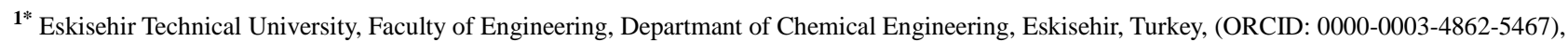 \\ evrenbayram@eskisehir.edu.tr \\ ${ }^{2}$ Eskisehir Technical University, Faculty of Engineering, Departmant of Chemical Engineering, Eskisehir, Turkey, (ORCID: 0000-0003-3705-4814), \\ gozde bahar turker@hotmail.com
}

(1st International Conference on Applied Engineering and Natural Sciences ICAENS 2021, November 1-3, 2021)

(DOI: $10.31590 /$ josat.1016237)

ATIF/REFERENCE: Büke, G.B. \& Arioz, E. (2021). Removal of Methylene Blue from Aqueous Solutions with Fly Ash Based Geopolymer Foam. European Journal of Science and Technology, (28), 1437-1441.

\begin{abstract}
Geopolymers are ceramic like materials synthesized by alkali activation of aluminosilicate powder at relatively low temperatures. Geopolymers have excellent properties such as high mechanical strength, high acid resistance, and high fire resistance. Depending on the properties of geopolymers, they have many application fields like adsorption, waste encapsulation, and construction industry. Adsorption is one of the remarkable application areas of geopolymers. Due to the increasing demand for clean water resources, the need for developments in water treatment is also increasing. Geopolymers offer cost effective and environmentally friendly alternatives to adsorbent materials. Many waste materials including fly ash and blast furnace slag can be used to synthesize geopolymeric materials. In this experimental study fly ash was used as raw material and geopolymer foam was produced by using 4 $\mathrm{M}$ sodium hydroxide and sodium silicate. Hydrogen peroxide was utilized to obtain foamed material. Fresh geopolymer paste cured at $80^{\circ} \mathrm{C}$ for 4 hours and then aged at laboratory conditions. Samples aged for 28 days were used in methylene blue removal from an aqueous solution. Adsorption experiments were carried out at laboratory conditions under normal light and under UV lamp in the presence of $\mathrm{TiO}_{2}$. The concentration of the solution obtained at the end of the adsorption contact time was determined by UV/VIS spectrophotometer at $665 \mathrm{~nm}$. The effect of adsorbent ratio and temperature on removal efficiency and adsorption capacity were investigated. The highest removal efficiency values were obtained as $92 \%$ and $83 \%$ under UV lamp and normal light, respectively. The results indicated that geopolymers are very promising materials that can be used in methylene blue removal.
\end{abstract}

Keywords: Geopolymer, Adsorption, Methylene blue.

\section{Uçucu Kül Esası Geopolimer Köpük ile Sulu Çözeltilerden Metilen Mavisi Giderimi}

Öz

Geopolimerler, alüminosilikat içeren toz halindeki malzemenin alkali aktivasyonu ile nispeten düşük sıcaklıklarda sentezlenen seramik benzeri malzemelerdir. Geopolimerler, yüksek mekanik mukavemet, yüksek asit direnci, yüksek yangın direnci gibi mükemmel özelliklere sahiptirler. Geopolimerler, özelliklerine bağlı olarak adsorpsiyon, atık kapsülleme ve inşaat sektörü gibi birçok uygulama alanına sahiptirler. Adsorpsiyon, geopolimerlerin dikkat çekici uygulamalarından birisidir. Temiz su kaynaklarına olan talebin artması nedeniyle su arıtımındaki gelişmelere duyulan ihtiyaç da artmaktadır. Geopolimerler, uygun maliyetli ve çevre dostu olmalarıyla adsorban olarak kullanılan malzemelere alternatifler sunmaktadırlar. Uçucu kül ve yüksek firın cürufu dahil olmak üzere birçok atık malzeme, geopolimerik malzemelerin sentezinde kullanılabilirler. Bu deneysel çalışmada, hammadde kaynağı olarak uçucu kül kullanılmıştır. 4 M sodyum hidroksit, sodyum silikat ile karıştırılmış ve uçucu küle eklenmiştir. Geopolimer köpük eldesi amacı ile karışıma hidrojen peroksit ilave edilmiştir. Geopolimer karışımı $80^{\circ} \mathrm{C}^{\prime} \mathrm{de} 4$ saat kür edilmiştir ve laboratuvar koşullarında yaşlandırılmıştır. Sulu çözeltiden metilen mavisi gideriminde 28 günlük numuneler kullanılmıştır. Adsorpsiyon deneyleri, laboratuvar koşullarında normal 1şık altında ve UV lambası altında $\mathrm{TiO}_{2}$ varlığında gerçekleştirilmiştir. Adsorpsiyon süresinin sonunda elde edilen çözeltinin konsantrasyonu, $665 \mathrm{~nm}$ dalga boyunda UV/VIS spektrofotometre ile belirlenmiştir. Adsorban oranı ve sıcaklığın, giderim verimi ve adsorpsiyon kapasitesi üzerindeki etkisi araştırılmıştır. En yüksek giderim verimi UV lambası altında \%92, normal ışık altında ise \%83 olarak elde edilmiştir. Sonuçlar, geopolimerlerin metilen mavisi gideriminde kullanılabilecek çok umut verici malzemeler olduğunu göstermiştir.

Anahtar Kelimeler: Geopolimer, Adsorpsiyon, Metilen mavisi.

*Corresponding Author: evrenbayram@eskisehir.edu.tr 


\section{Introduction}

The increase in population and industrialization have caused the pollution of clean water resources. Many pollutants such as dyes, heavy metals, surfactants cause pollution of water resources. The contamination of surface and ground water is harmful to both ecosystem and humans $[1,2]$. Dyes are widely used contaminants in many industries.

Dyes are widely used in the textile, leather, printing, paper, food, cosmetics, gasoline, pharmaceutical, automotive, and other coloring industries [3, 4]. More than 100,000 different types of dye are produced annually, about 700,000 tons. Many techniques such as adsorption, photodegradation, and membrane separation are used in wastewater treatment $[3,5]$. Adsorption is the most widely used technique due to its simple design, ease of use and cost-effectiveness [4]. Photodegradation is the degradation of organic pollutants under UV light [6]. $\mathrm{TiO}_{2}$ is often used as a photocatalyst because of its chemical stability and non-toxicity [7].

Various adsorbent materials including activated carbon, clay, zeolites, fly ash and geopolymers are used to remove pollutants from wastewater $[1,3]$. In recent years, researchers have focused on the production of cost-effective and environmentally friendly adsorbent materials [8].

Geopolymers are low-cost, environmentally friendly materials with superior properties and thermal stability $[9,10]$. Geopolymers can be used in many fields such as adhesives, coatings and hydroceramics [11].

Geopolymerization begins with the dissolution of the species exist in the raw material. The dissolved species form a gel phase and condense to form a three dimensional network [12, 13] with the empirical formula: $\mathrm{M}_{\mathrm{n}}\left[-\left(\mathrm{SiO}_{2}\right)_{\mathrm{z}}-\mathrm{AlO}_{2}\right]_{\mathrm{n}} \cdot \mathrm{wH}_{2} \mathrm{O}$, where $\mathrm{z}$ is 1,2 or $3 ; \mathrm{M}$ is an alkali cation such as potassium or sodium and $n$ is the degree of polymerization $[14,15]$.

Geopolymers, also called inorganic polymers, can be synthesized by both natural raw materials and waste materials $[16,13]$. Geopolymers exhibit superior properties and characteristics such as high compressive strength, low shrinkage, resistance to acids, and low thermal conductivity [11]. Waste materials rich in silicon and alumina can be used for geopolymerization. Different raw materials result in geopolymers with different properties, structures and fields of application [17].

Fly ash is a by-product of coal combustion thermal power plant. Fly ash consists of fine particles and is rich in silicon and aluminum. The content of fly ash makes it a suitable raw material for geopolymerization [18]. Worlwide, 780 million tonnes of fly ash is produced annually, but about $17-20 \%$ of it is utilized [19].

In this study, fly ash based geopolymer foam was used for methylene blue removal from aqueous solutions. Methylene blue is a cationic dye used primarily used in the textile industry, leather dyeing and furniture coloring [4, 20, 21]. Methylene blue should be removed from wastewater because it is biohazardous and carcinogenic for some marine species [22].

\section{Material and Method}

\subsection{Synthesis of Geopolymer}

Class F fly ash was used in the production of geopolymer foam. $4 \mathrm{M}$ sodium hydroxide was added to sodium silicate to obtain the activator solution. The activator solution was poured onto the fly ash and stirred for 5 minutes. Hydrogen peroxide was added to the geopolymer slurry. After mixing, geopolymer foam paste was cast into $4 \times 4 \times 16 \mathrm{~mm}$ moulds. The pastes were cured in a laboratory oven at $80^{\circ} \mathrm{C}$ for 4 hours.

The cured samples removed from the oven were aged for 7 and 28 days under atmospheric conditions. Compressive strength tests were carried out on samples aged for 7 and 28 days. Samples cured for 28 days were crushed and used as an adsorbent for methylene blue removal.

Samples cured for 28 days were crushed and used as adsorbent for methylene blue removal.

\subsection{Adsorption Experiments}

Adsorption experiments were carried out in two groups, under normal conditions and under UV lamp in the presence of $\mathrm{TiO}_{2}$. A methylene blue solution was prepared at a concentration of $200 \mathrm{mg} / \mathrm{L}$ concentration. The amount of geopolymer foam sample ground as adsorbent varied between $0.1 \mathrm{~g}$ and $1 \mathrm{~g}$. The effects of temperature $\left(30^{\circ} \mathrm{C}\right.$ and $\left.40^{\circ} \mathrm{C}\right)$ and contact time $(1 \mathrm{~h}, 2 \mathrm{~h}$ and $3 \mathrm{~h}$ ) on the removal efficiency and adsorption capacity were investigated. Photocatalytic degradation experiments of methylene blue were carried out under a $\mathrm{UV} \mathrm{TiO}_{2}$-catalyzed UV lamp. $\mathrm{TiO}_{2}$ amount remained constant as $0.5 \mathrm{~g}$ in all experiments. At the end of the adsorption experiments, the mixtures were centrifuged and the concentrations of the solutions at the given contact times were determined by UV/VIS spectroscopy at a wavelength of $665 \mathrm{~nm}$. The removal efficiency and adsorption capacity were calculated using the equations given below:

$$
\text { Removal Efficiency }(\%)=\frac{C_{o}-C_{t}}{C_{o}} \times 100
$$

$$
\text { Adsorption Capacity }=\mathrm{q}_{\mathrm{t}}=\frac{\left(C_{o}-C_{t}\right) V}{m}
$$

where $C_{o}$ is the initial concentration, $C_{t}$ is the concentration at given time $\mathrm{t}, \mathrm{V}$ is the volume of the solution and $\mathrm{m}$ is the adsorbent amount.

\section{Results and Discussion}

\subsection{Characteristics of Geopolymer Sample}

The compressive strength of the 7-day and 28-day aged samples were measured as $3.1 \mathrm{MPa}$ and $4 \mathrm{MPa}$, respectively. The FTIR spectrum of the 28-day aged geopolymer sample is given in Figure 1.

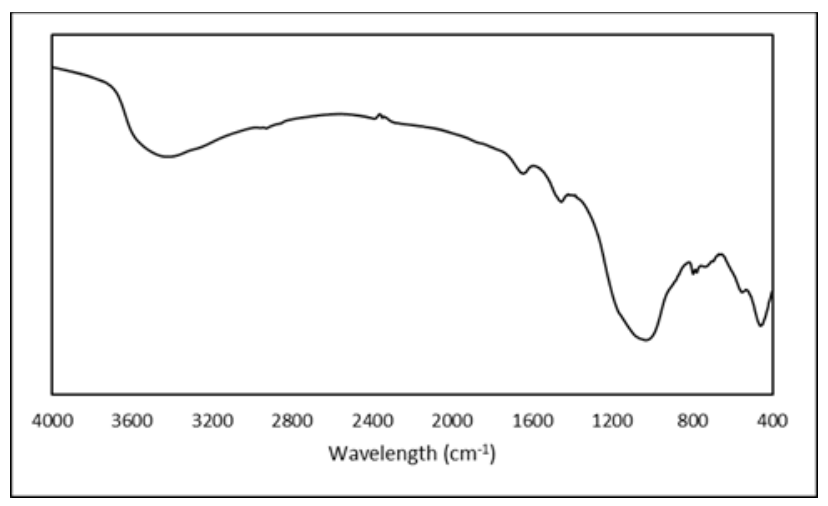


Fig. 1 FTIR spectrum of sample cured for 28 days

The main peak which is the fingerprint of geopolymers observed at about $1000 \mathrm{~cm}^{-1}$, is assigned to the $\mathrm{Si}-\mathrm{O}-\mathrm{Si}$ stretching vibration [23]. $\mathrm{Si}-\mathrm{O}-\mathrm{Si}$ and $\mathrm{Si}-\mathrm{O}-\mathrm{Al}$ (bending mode) vibrations were observed at $470 \mathrm{~cm}^{-1}$ [24]. The band seen at $1450 \mathrm{~cm}^{-1}$ is attributed to stretching vibrations of $\mathrm{C}=\mathrm{O}$ confirming the presence of carbonate groups [25]. The broad band seen at $3400 \mathrm{~cm}^{-1}$ is associated with $-\mathrm{OH}$ stretching, and the band at $1655 \mathrm{~cm}^{-1}$ corresponds to $\mathrm{H}-\mathrm{O}-\mathrm{H}$ bending [15].

\subsection{Adsorption Experiments}

The adsorption experiments were carried out at normal conditions and $\mathrm{UV}$ light at $30^{\circ} \mathrm{C}$ and $40^{\circ} \mathrm{C}$ with varying adsorbent amount. The removal efficiency percentages obtained at $30^{\circ} \mathrm{C}$ under normal conditions are given in Figure 2.

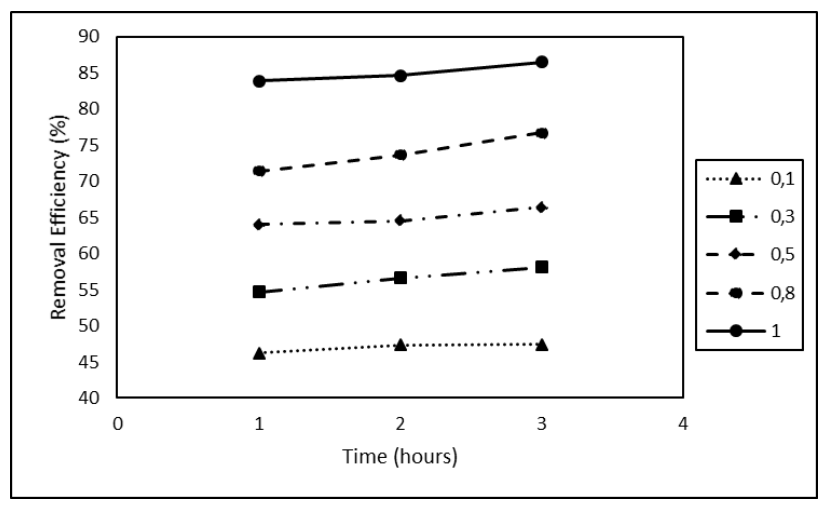

Fig. 2 Removal efficiency values obtained at $30^{\circ} \mathrm{C}$

With the increasing amount of geopolymer foam, the removal efficiency percentages increased significantly. The highest removal percentage was obtained as $86.5 \%$ in 3 hours contact time when $1 \mathrm{gr}$ adsorbent was used. Contact time did not significantly affect methylene blue removal. The adsorption capacity $\left(\mathrm{q}_{\mathrm{t}}\right)$ under the same conditions is given in Figure 3.

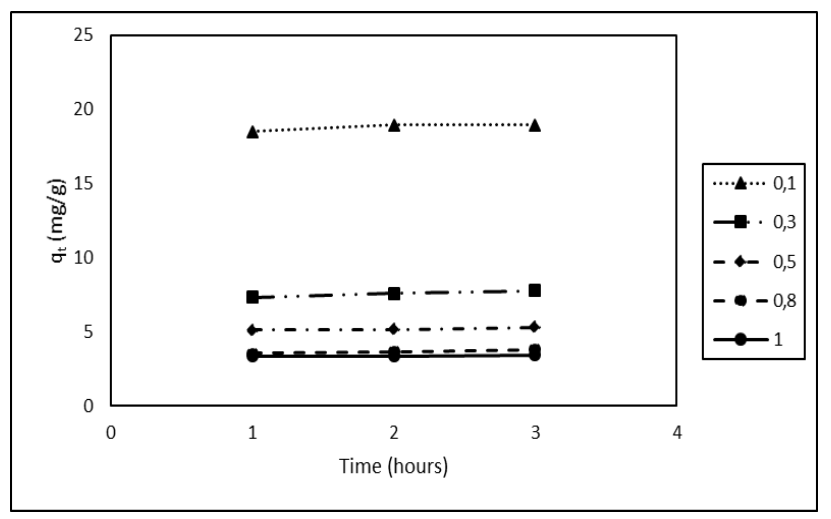

Fig. 3 Adsorption capacity values obtained at $30^{\circ} \mathrm{C}$

Adsorption capacity values decreased with increasing amount of adsorbent due to the formula, but the decrease was very sharp when the amount of adsorbent increased from $0.1 \mathrm{~g}$ to $0.3 \mathrm{~g}$. The capacities were approximately the same when the amounts of geopolymer foam were $0.8 \mathrm{~g}$ and $1 \mathrm{~g}$. The removal efficiencies achieved at $40^{\circ} \mathrm{C}$ are given in Figure 4.

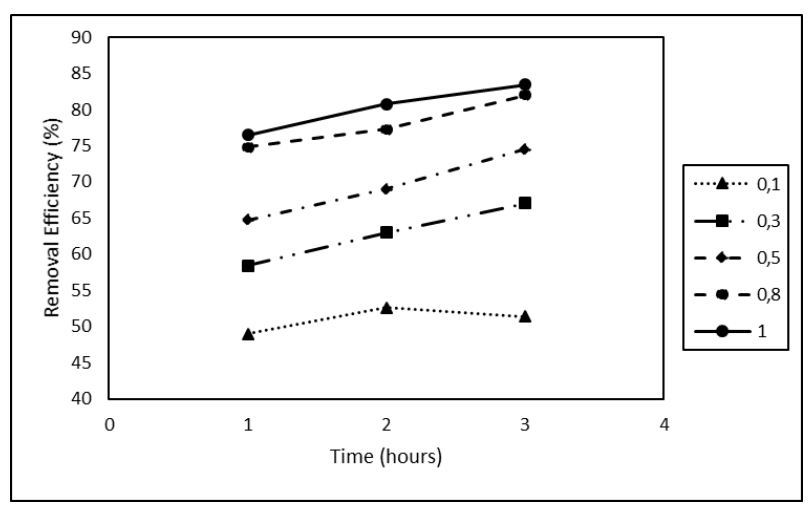

Fig. 4 Removal efficiency values obtained at $40^{\circ} \mathrm{C}$

As expected, efficiencies increased with increasing adsorbent amount. The highest removal efficiency was found as $83.5 \%$ It was observed that the removal efficiency increased slightly with increasing temperature. The adsorption capacity $\left(\mathrm{q}_{\mathrm{t}}\right)$ values at $40^{\circ} \mathrm{C}$ are given in Figure 5 .

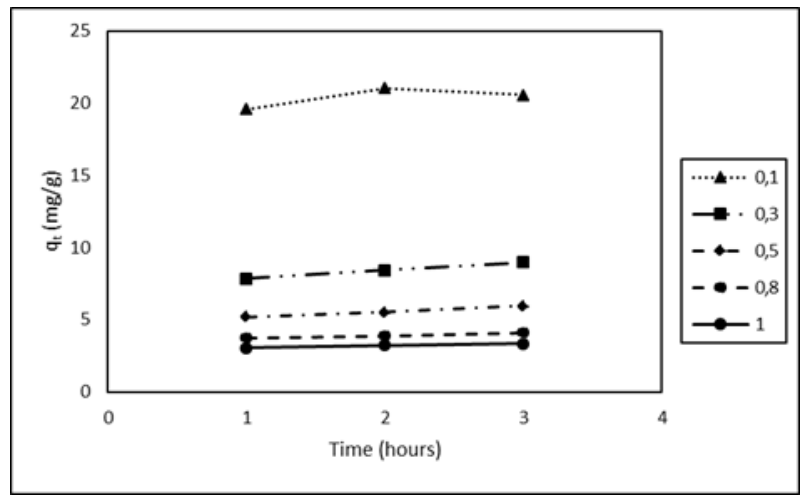

Fig. 5 Adsorption capacity values obtained at $40^{\circ} \mathrm{C}$

The change in the amount of adsorbent with the adsorption capacity is the same as at $30^{\circ} \mathrm{C}$. The capacities decreased with the increasing amount of adsorbent. Values were almost identical to capacities at $30^{\circ} \mathrm{C}$.

Photocatalytic degradation experiments were carried out under UV lamp with a fixed amount of $\mathrm{TiO}_{2}$ as catalyst. The removal efficiency obtained with $0.5 \mathrm{~g} \mathrm{TiO}_{2}$ at $40^{\circ} \mathrm{C}$ under UV light are given in Figure 6. 


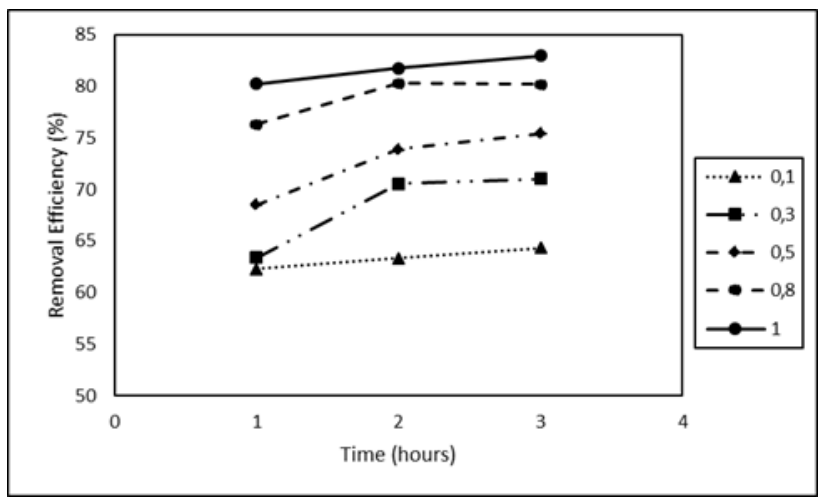

Fig. 6 Removal efficiency values obtained at $30^{\circ} \mathrm{C}$ under UV light

As the amount of geopolymer foam increased, the removal efficiency values also increased. Compared to the values found in the adsorption experiments performed under normal conditions, the removal values increased under UV light. The increase was low for the removal values obtained for $1 \mathrm{~g}$ under normal conditions. Adsorption capacities at $30^{\circ} \mathrm{C}$ under UV light are given in Figure 7.

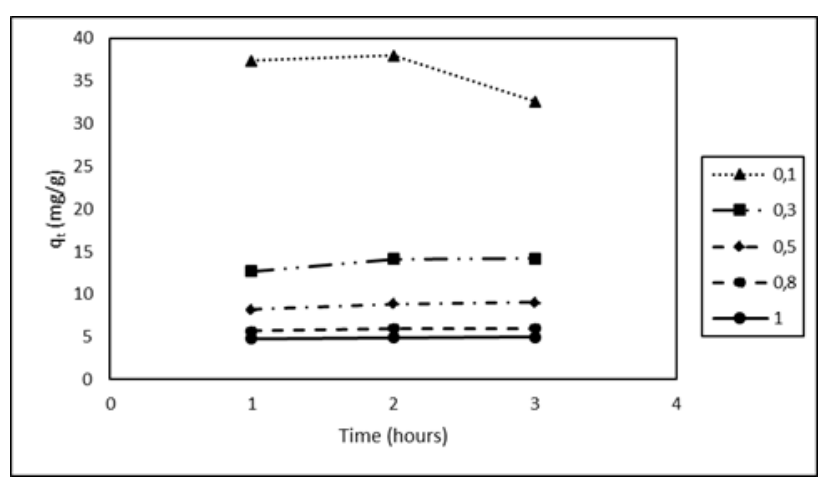

Fig. 7 Adsorption capacity values obtained at $30^{\circ} \mathrm{C}$ under UV light

As can be seen from the figure, the change in adsorption capacities was the same as found at $30^{\circ} \mathrm{C}$, except for the increase in time when increased to $3 \mathrm{~h}$ for $0.1 \mathrm{~g}$ adsorbent. The values have increased approximately two times over the values found under normal conditions. Removal efficiencies at $40^{\circ} \mathrm{C}$ under UV light are given in Figure 8.

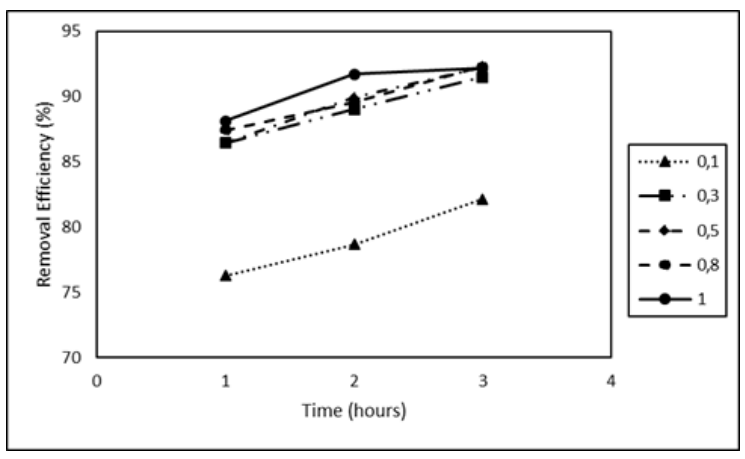

Fig. 8 Removal efficiency values obtained at $40^{\circ} \mathrm{C}$ under UV light

It is seen from the figüre that the efficiency values are close to each other for adsorbent amounts between $0.3 \mathrm{~g}$ and $1 \mathrm{~g}$. The removal efficiency values varied between the lowest $76 \%$ and the highest $92 \%$ in 0.1 gr adsorbent for 1 hour and at 1 gr adsorbent for 3 hours, respectively. Adsorption capacities at $40^{\circ} \mathrm{C}$ under UV light are given in Figure 9.

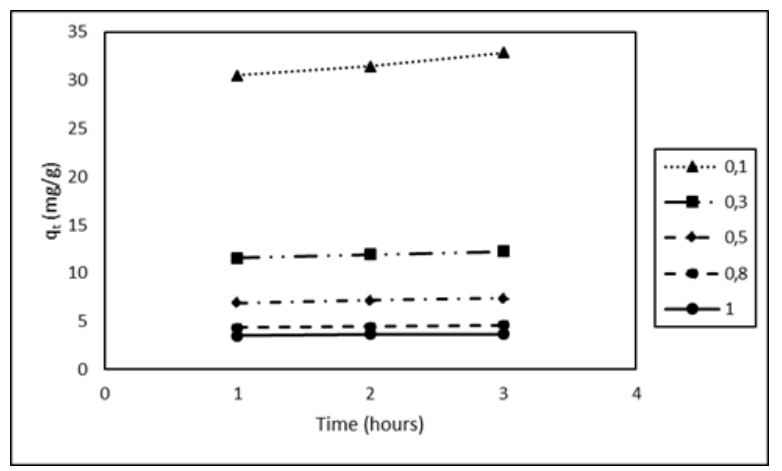

Fig. 9 Adsorption capacity values obtained at $40^{\circ} \mathrm{C}$ under UV light

Adsorption capacity values obtained under UV light were found to be approximately 2 times higher than those obtained under normal conditions. The highest adsorption capacity was found to be $32.9 \mathrm{mg} / \mathrm{g}$ for $0.1 \mathrm{~g}$ adsorbent for 3 hours.

Photodegradation under UV light with $\mathrm{TiO}_{2}$ catalyst and increase in temperature positively affected the removal efficiency and adsorbent capacity. Removal efficiencies increased significantly with temperature under UV light.

\section{Conclusions and Recommendations}

The results obtained from the experimental study showed that the geopolymer foam was successfully synthesized by fly ash under the specified conditions. Fingerprinting of geopolymers observed in the FT-IR spectrum. The dye removal efficiency and the adsorption capacity values obtained in this experimental study were found to be quite high when compared with the literature $[26,21]$. The results were promising, as the removal efficiency and adsorption capacity values were obtained at high values with high initial dye concentration.

The results revealed that the geopolymer foam synthesized in this study can be used for methylene blue removal. Geopolymer foams offer sustainable and environmentally friendly solutions for both the utilization of fly ash and wastewater treatment. Geopolymers can be synthesized under different conditions such as curing temperature and duration, sodium hydroxide ratio and can be studied for the removal of different types of dyes in further studies.

\section{Acknowledge}

This experimental study was supported by the Eskisehir Technical University research project No: 20ADP197.

\section{References}

[1] A. A. Siyal, M. R. Shamsuddin, M. I. Khan, N. E. Rabat, M. Zulfiqar, Z. Man, J. Siame and K. A. Azizli, 'A review on geopolymers as emerging materials for the adsorption of heavy metals and dyes', Journal of Environmental Management, vol. 224, pp. 327-339, 2018. 
[2] M. E. Alouani, H. Saufi, G. Moutaoukil, S. Alehyen, B. Nematollahi, W. Belmaghraoui and T. Taibi, 'Application of geopolymers for treatment of water contaminated with organic and inorganic pollutants: State-of-the-art review', Journal of Environmental Chemical Engineering, vol. 9, 105095, 2021.

[3] K. Kaya-Özkiper, A. Uzun and S. Soyer-Uzun, 'A novel alkali activated magnesium silicate as an effective and mechanically strong adsorbent for methylene blue removal', Journal of Hazardous Materials, vol. 424, 127256, 2022.

[4] J. Ramírez-Aparicio, J. E. Samaniego-Benítez, M. A. Murillo-Tovar, J. L. Benítez-Benítez, E. Mũnoz-Sandoval and M. L. García-Betancourt, 'Removal and surface photocatalytic degradation of methylene blue on carbon nanostructures', Diamond \& Related Materials, vol. 119, 108544, 2021.

[5] O. Moradi and G. Sharma, 'Emerging novel polymeric adsorbents for removing dyes from wastewater: A comprehensive review and comparison with other adsorbents', Environmental Research, vol. 201, 111534, 2021.

[6] H. Saufi, M. E. Alouani, S. Alehyen, M. E. Achouri, J. Aride and M. Taibi, 'Photocatalytic degradation of methylene blue from aqueous medium onto perlite-based geopolymer', International Journal of Chemical Engineering, vol. 2020, Article ID 9498349, 2020.

[7] S. Liu, C. Zuo and J. Xia, 'Solid-state synthesis and photodegradation property of anatase $\mathrm{TiO}_{2}$ micronanopowder by sodium replacement', Solid State Sciences, vol. 115, 106589, 2021.

[8] Y. O. Khaniabadi, R. Heydari, H. Nourmoradi, H. Basiri and H. Basiri, 'Low-cost sorbent for the removal of aniline and methyl orange from liquid-phase: Aloe Vera leaves wastes', Journal of the Taiwan Institute of Chemical Engineers, vol. 68, pp. 90-98, 2016.

[9] Y. Zhang and L. Liu, 'Fly ash-based geopolymer as a novel photocatalyst for degradation of dye from wastewater', Particuology, vol. 11, pp. 353- 358, 2013.

[10] L. Chen, K. Zheng and Y. Liu, 'Geopolymer-supported photocatalytic $\mathrm{TiO}_{2}$ film: Preparation and characterization', Construction and Building Materials, vol. 151, pp. 63-70, 2017.

[11] P. Duxon, A. Fernandez-Jimenez, J.L. Provis, G.C. Lukey, A. Palomo and van Deventer J.S.J., 'Geopolymer technology: The current state of the art', Journal of Materials Science, vol. 42, pp. 2917-293, 2007

[12] E.I. Diaz, E.N. Allouche and S. Eklund, 'Factors affecting the suitability of fly ash as source material for geopolymers', Fuel, vol. 89, pp. 992-996, 2010.

[13] B. Singh, G. Ishwarya, M. Gupta and S.K. Bhattacharyya, 'Geopolymer concrete: A review of some recent developments', Construction and Building Materials, vol. 85, pp. 78-90, 2015.

[14] T. Bakharev, 'Geopolymeric materials prepared using Class F fly ash and elevated temperature curing', Cement and Concrete Research, vol. 35, pp. 1224- 1232, 2005.

[15] E. Alvarez-Ayuso, X. Querol, F. Plana, A. Alastuey, N. Moreno, M. Izquierdo, O. Font, T. Moreno, S. Diez, E. Vazquez and M. Barra, 'Environmental, physical and structural characterisation of geopolymer matrixes synthesised from coal (co-) combustion fly ashes', Journal of Hazardous Materials, vol. 154, pp. 175-183, 2008.
[16] P. Cong and Y. Cheng, 'Advances in geopolymer materials: A comprehensive review', Journal of Traffic and Transportation Engineering (English Edition), vol. 8(3), pp. 283-314, 2021.

[17] B. Ren, Y. Zhao, H. Bai, S. Kang, T. Zhang and S. Song, 'Eco-friendly geopolymer prepared from solid wastes: A critical review', Chemosphere, vol. 267, 128900, 2021.

[18] Y. H. M. Amran, R. Alyousef, H. Alabduljabbar, M. ElZeadani, 'Clean production and properties of geopolymer concrete; A review', Journal of Cleaner Production, vol. 251, 119679, 2020.

[19] S. K. John, Y. Nadir and K. Girija, 'Effect of source materials, additives on the mechanical properties and durability of fly ash and fly ash-slag geopolymer mortar: A review', Construction and Building Materials, vol. 280, 122443, 2021.

[20] P. Rożek, M. Król and W. Mozgawa, 'Lightweight geopolymer-expanded glass composites for removal of methylene blue from aqueous solutions', Ceramics International, vol. 46, pp. 19785-19791, 2020.

[21] D. Wattanasiriwech, K. Yomthong and S. Wattanasiriwech, 'Adsorption efficiency and photocatalytic activity of fly ash-based geopolymer foam mortar', Ceramics International, vol. 47, pp. 27361-27371, 2021.

[22] T. de O. Guidolin, N. M. Possolli, M. B. Polla, T. B. Wermuth, T. F. de Oliveira, S. Eller, O. R. K. Montedo, S. Arcaro and M. A. P. Cechinel, 'Photocatalytic pathway on the degradation of methylene blue from aqueous solutions using magnetite nanoparticles', Journal of Cleaner Production, vol. 318, 128556, 2021.

[23] G. S. Ryu, Y. B. Lee, K. T. Koh and Y. S. Chung, 'The mechanical properties of fly ash-based geopolymer concrete with alkaline activators', Construction and Building Materials, vol. 47, pp. 409-418, 2013.

[24] H. Oudadesse, A. C. Derrien and M. Lefloch, 'Infrared and nuclear magnetic resonance structural studies vs. thermal treatment of geopolymers/biphasic calcium phosphates', Journal of Thermal Analysis and Calorimetry, vol. 82, pp. 323-329, 2005.

[25] S. K. Nath, S. Maitra, S. Mukherjee and S. Kumar, 'Microstructural and morphological evolution of fly ash based geopolymers', Construction and Building Materials, vol. 111, pp. 758-765, 2016.

[26]A. Maleki, M. Mohammad, Z. Emdadi, N. Asim, M. Azizi, J. Safaei, 'Adsorbent materials based on a geopolymer paste for dye removal from aqueous solutions', Arabian Journal of Chemistry, vol. 13, pp. 3017-3025, 2020. 